\title{
Analysis and Design of Internal Control on Barter Process in News Website Company
}

\author{
Yovita Ariani \\ Magister Akuntansi Ekonomi dan Binsis \\ Universitas Indonesia \\ Indonesia \\ mkyovita_ariani@yahoo.com \\ Lufti Julian \\ Magister Akuntansi Ekonomi dan Bisnis \\ Universitas Indonesia \\ Indonesia \\ 1j1.joel@gmail.com
}

\begin{abstract}
In the era of technology, the role of mass media in the communication media is very important for disseminating information and promoting companies' products. Companies need to allocate huge marketing costs when they use mass media to market their products. Conversely, mass media require products from companies to fulfill their internal needs and to enhance brand image. The existence of each parties' needs can lead to barter transactions. The problem that can arise in this barter process is the difference between establishing the barter value from the actual value. Also, insufficient barter goods management can harm the company. The purpose of this research is to analyze the barter process at PT. X, one of the mass media companies, to generate policy and procedure recommendations for the implementation of internal control processes and provide valuable information for decision-making. This qualitative case study research on PT.X analyzes data from observations, interviews, and documentation to reach its conclusions. The results showed that there are weaknesses in the barter process at PT. $X$ as shown by the inadequate segregation of duties and the absence of policies. Adequate policies and procedures should be developed to mitigate the risks.
\end{abstract}

Keywords-Barter; mass media; policies; procedure; internal control; advertisement; website

\section{INTRODUCTION}

The purpose of this research is to understand and analyze the process in sales and to determine the barter value, the barter goods management and the barter incentive mechanisms to make suggestions or improve the policies and procedures. In this study, the researchers only discuss the design of internal control with respect to risk assessment and control activities, and does not cover the effectiveness of the implementation of internal control. This research is important because there is limited literature on barter, specifically on risk and internal control related to value determination and the management of barter goods.

In the current technological era, mass media plays a very important role in disseminating information to the public including the marketing of the company's products. The types of mass media range from newspapers and radio to social and digital media, including websites. In this digital age with its need for immediate gratification, digital media plays a very important in disseminating information by providing news, education and entertainment; digital media cannot be separated from everyday life. A Nielsen [1] report in The new trend among Indonesia's netizens, shows that internet usage has a $44 \%$ market penetration, which ranks third after television and outdoor static media. One way companies market using digital media is through the company's website providers such as well-known news and entertainment portal providers. The marketing activities of the company's products on these websites require the allocation of marketing costs, and often companies do not have a marketing budget. However, website providers require the company products for their internal needs such as events and operational supply which enhance the image of the website provider's brand. The existence of each parties' needs can lead to barter transactions that are transactions when goods or services are exchanged with other goods or services without using money [2].Therefore, it is important for the company to examine the barter value and the need for barter goods to ensure that it will receive the same value as the advertising provided by the website provider. This research was conducted on PT. X, a website provider that uses barter as part of its sales activities. PT. X can answer questions that arise out of barter, including the determination of barter values, barter goods management, and barter incentive methods.

In this study, the author tries to answer the question of how internal controls can play a role in the process of selling and establishing barter values, how companies conduct processes and policies on barter management to protect themselves from loss, and how incentive mechanisms and policies affect the achievement of sales through barter. The analysis of the process and policy is done on the basis of a research question, to propose or improve the policies and procedures in the standard operating procedures (SOPs). This study applied a qualitative case study approach using 
primary and secondary data. The research method consisted of observations, interviews, and documentation.

This paper comprises five parts. The introduction discusses the research aims, the problems, the importance of the research, and a generally discussion on the approach used. The next section consists of a literature review that discusses the basic theories used in internal control, accounting information systems (AIS), barter, and SOPs as the basis for analysis and recommendations. The third section discusses the research methodology comprising the methods and data used as well as the unit analysis. Discussions on implementation, risk analysis and internal control, the findings obtained, and the proposed improvements are discussed in the fourth section. The fifth section will discuss the conclusions of the study, research limitations, and proposals for further research. The last section will include a list of references used in this paper.

\section{LITERATURE REVIEW}

It is important to have an understanding of the internal control that will be described in this chapter to address the topic of this paper. Such an understanding will assist in providing answers on aspects of internal control.

\section{A. Internal Control}

Arens [3] defines internal controls as comprising policies and procedures designed to provide reasonable assurance for management that the organization can achieve its objectives of reliability of financial statements, effectiveness and efficiency of operations, and compliance with laws and regulations. Internal control is the process part of an organization's activities that provide adequate guarantees, although not entirely due to limitations that include high implementation costs and inherent limitations such as "mismaking" decisions [4]. From this definition, it is apparent that internal control involves the entire organization to achieve its objectives of effective and efficient operational activities, improvement of the reliability of financial statements, and compliance with laws and regulations.

For an organization to achieve its objectives, it is necessary to have an effective internal control consisting of five components based on the Committee of Sponsoring Organizations of the Treadway Commission (COSO) framework namely, the control environment, risk assessment, control activities, information and communication, and the monitoring of activities. These five components can be run by all levels of the organization, both at the organizational level and at branch level, as well as divisions, functions, and departments. Internal control should also be able to assist the company in achieving its objectives as included in the management statement contained in the financial statements.

\section{B. Accounting Information System (AIS) in Understanding Internal Control}

Good information is relevant, reliable, complete, timely, understandable, verifiable, and accessible to assist management in decision-making. Therefore, it is necessary to have an AIS to understand risk and internal control. According to Romney [4], AIS is a system to collect, record, store, and process data to generate information for decisionmaking. To implement AIS, business processes must be well understood and provide an overview of the organization's current operational activities that can be used as a basis for process improvement to be more effective and efficient. We can use graphic representation in the form of business process diagrams that show the various steps or activities in a business process [4] to understand business processes.

\section{Barter}

According to Healey [2] in a study titled Why is corporate barter?, barter is a common form of transaction where goods or services are exchanged for other goods or services without the use of money. Healey argues that one of the reasons organizations barter is because organizations cannot find buyers who are willing to use money to pay for their products, so organizations prefer to barter by trading their products or services with the products or services that they need. In other words, barter occurs without the use of currency and benefits both parties. According to Healey, organizations can use barter to lower costs, and when using mass media, they can maximize empty advertising spots.

Another advantage of barter is to disguise the discount received while maintaining the selling price of goods or services exchanged, so the competitor does know the discount policy. Despite the use of barter in media organizations, there are some difficulties or weaknesses. According to research conducted by Kassaye and Vaccaro [5] in the Journal of Advertising Research titled TV stations use of barter to finance programs and advertisements, there is a negative perception of barter because station and advertiser objectives are competitive rather than fulfilling mutual needs. In addition, Kassaye [5] also stated that in barter execution there are difficulties because it is necessary for both parties to have the same desire, and finding that market is not easy. The second difficulty is in determining the real price of barter goods because of the difference in the type of goods. Also, other difficulties include limited choices, inflexible credit payment, and the difficulty in storing barter goods. Therefore, establishing barter value is very important.

\section{Incentive}

Compensation is all income in the form of money and goods, either direct or indirect, in return for services provided by employees to the company [6]. The purpose of compensation is to increase job satisfaction; it is both a tool to motivate employees and a tool to boost employee productivity. Incentives, as a form of compensation, are given as a reward to certain employees, whose performance is above standard [6]. It is clear, based on this definition, that the main purpose of providing incentives is to encourage employee productivity to benefit the company. This incentive method must be well planned for the incentives to succeed.

\section{E. Standard Operating Procedures (SOPS)}

To assist the organization in achieving its vision and mission goals, guidelines such as SOPs and policies are required to carry out operational and decision-making activities. Tambunan [7], states that SOPs contain operational procedures within an organization that ensure that the decisions and actions taken by people within the organization are effective, efficient, consistent, standardized, and systematic. From the above definition, it is clear that the purpose of the SOPs is to standardize and guide the staff of an organization in carrying out their work. Good SOPs that considers the internal control and operational activities in 
organizations can be effective because they shows consistency, commitment, and continuous improvement.

\section{RESEARCH METHOD}

This study uses a single case which is only limited to the object of writing (unit analysis) at PT. X. This research follows a qualitative case study approach to deepen and respond to more detailed phenomena by using different viewpoints. According to Yin's [8] definitions of case study, this approach will be able helpful in answering this paper's questions about internal control in the barter process and barter goods management. The authors of this study use qualitative methods to collect, design, and analyze data. In this paper, data was obtained from two sources. The first source is primary data that refers to information obtained from a direct source related to research objectives. The primary data source used in this paper consists of individual respondents. The second data source used is secondary data that refers to information collected from existing sources that are used as a complementary data and comparison material. The secondary data sources used in this paper are company records or documentation, publications, literature, and websites.

The data collection method used by the researchers is direct unstructured observation so that the researchers can develop the object of observation to meet the research objectives. The researcher records, in detail, the observation time, keywords, place of observation, and events occurring during the observation. The researchers also use the method of systematic and directional interviews adjusted to the respondents' circumstances. In a systematic interview, the researcher prepare a list of questions that will be put to the respondent as a guide in the interview process. In directional interviews, the researcher conducts interviews freely without using a list of questions, but keeps to the core issues to be discussed. The last method used by the author is the documentation of the company's internal documents in the form of financial statements, advertising price list (rate card), a list of barter goods, and policies related to the process of barter. From the data collection method selected, the researcher then conducts data analysis to provide in-depth discussion of the information obtained during the data collection stage.

\section{A. Analytical Unit}

PT. X is a subsidiary of a media company in Indonesia, which aims to develop websites for online news portals and entertainment in the Indonesian language. The company focuses on delivering wide, fast, complete, and timely news coverage to provide information to the public. Based on the company's corporate structure, the company is divided into four major areas to support its operational activities such as sales marketing, content, operation technology, and backline operation. As part of its sales strategy, PT.X barters to meet operational needs and achieve targets.

\section{RESEARCH FINDINGS AND DISCUSSION}

\section{A. Implementation and Analysis of Sales and Barter Value \\ Determination}

Barter sales start from the sales division under the sales and marketing directorate. The process starts when a request for a sales package is submitted by the section planning and implementation department by filling out a barter request package for the pre- and post-sales department. The package consists of internal and external packages. An external package that is approved by clients can be considered as purchase order for making a media order (MO). It consists of extensive information on the advertisement such as period, time, and advertisement type. The sales and planning and implementation department does not coordinate with the purchasing department when it determines the value of the barter goods. Information on the equality of the value of the barter goods compared with advertising value that the company provides to clients is not harmonized. Also, those two departments do not coordinate with the general services department regarding the availability of goods in the warehouse and the needs for goods. The company has no guidance on the determination of the sales category, the barter goods category that can be accepted by company, and the process in determining the barter value.

Risks that may arise are due to the lack of guidance when the barter items received do not match the value of advertisements assigned to clients (Risk I), and the barter does not match the company's needs (Risk II). Both risks have a high financial impact which is reflected in the financial statements. Analysis of Risk I falls under the planning and implementation department which is part of the marketing department. The marketing department determines the price based on its own estimates without involving other parties such as purchasing and general services. Accordingly, it is possible that the value of the goods received from clients as barter compensation is actually less than the advertising value provided by the company. Risk II can occur when the sales department does not coordinate with purchasing and general services department on the company's internal needs. Consequently, the barter takes place solely to meet sales targets. To mitigate the consequences of Risk I, the company has internal control: marketing must conduct market price analysis to ascertain the fairness of the value of the goods. Nevertheless, the purchasing department has better access to pricing information because of its relationship with suppliers. Besides, referrals from independent parties (other than the sales and marketing division) will be better. Currently the company does not have internal control to mitigate the risks related to Risk II neither in the form of policies and procedures nor other controls. Therefore, the risk level for Risks I and II remain high.

Another risk that may arise is that an invalid advertisement is uploaded (Risk III). This risk level is high, because based on the organizational structure and interview results, booking slots for advertisements in barter transactions is done by employees in the marketing division. In this case, the determination of the barter value and the booking slot is done by same division without any reconciliation between the MO and the running of the advertisement which may result in an invalid advertisement. 

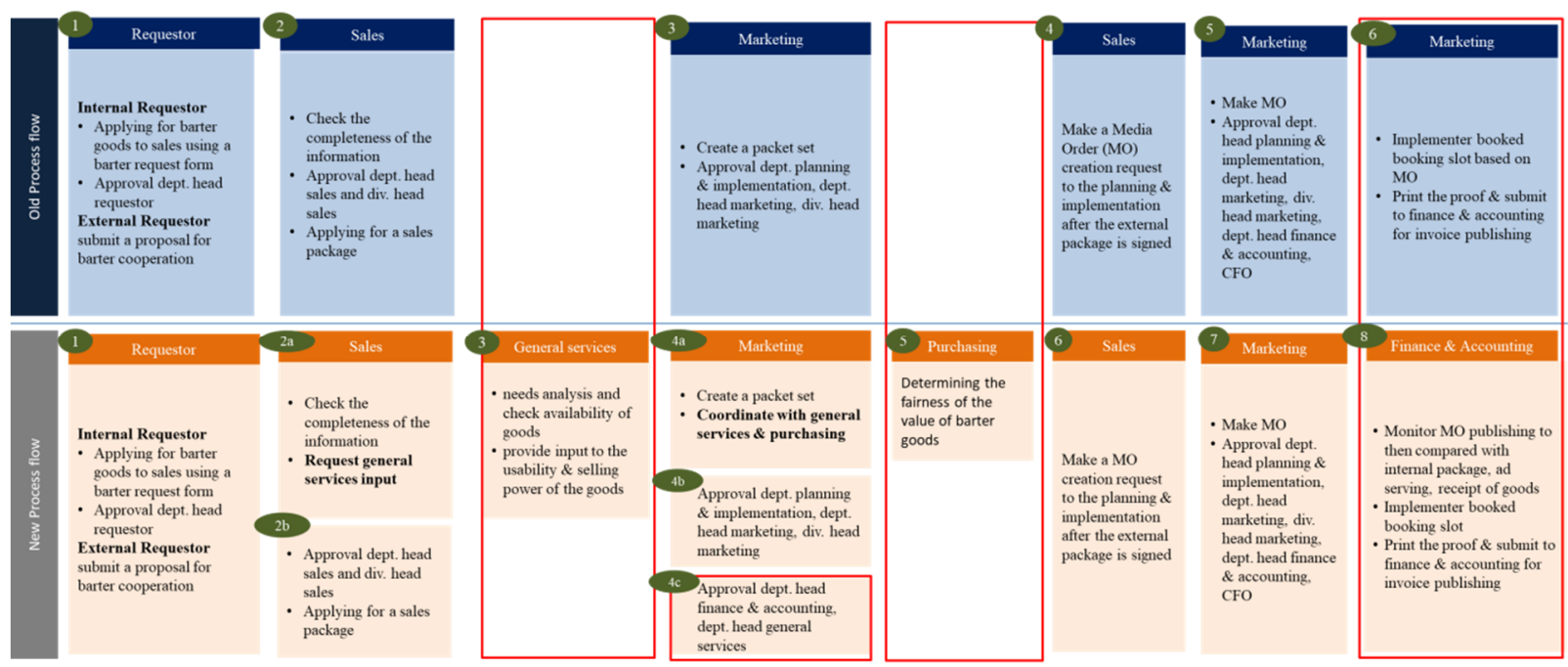

Fig. 1. Comparison of Old Process and Proposed Improvement

Completeness is also an objective in the barter sale so the company should consider the risk that barter sales are not recorded properly and correctly (Risk IV). Related to this matter, the finance and accounting department is not involved in the approval of the barter, so the validity of the barter value is only based on information from the sales department. The finance and accounting department only know about it when the MO is received before booking slot. The company has an unwritten policy to address Risks III and IV that the advertisement can only be displayed if the MO has been signed by the head of the finance and accounting department and the Chief Financial Officer (CFO). This unwritten policy can only partially reduce the risk level, because, there is no reconciliation to check the validity between when the MO is published and the advertisement is uploaded. The absence of clear policies and procedures within the company in relation to this process also increases the risk involved in the process.

Based on the above risk analysis and internal control on sales and barter value determination, it can be concluded that internal control has not been well-applied in the process, resulting in the internal control objectives not being achieved and causing harm to the company.

\section{B. Improvement in Sales and Barter \\ Value Determination}

To overcome the risks and weaknesses in internal control, the authors recommend improvements in business processes as well as the segregation of duties and responsibilities such as the transfer of the implementer section from marketing department to finance and accounting department,. The barter process can only be done after confirmation by the general services and purchasing departments and the approval by the finance and accounting department. The difference between the old process and the proposed improvement can be seen in Figure 1 which clearly shows the segregation of tasks in sales and barter values determination. Apart from that, there are important things that need to be established that barter sales can only be done if there is an internal need in the company or to increase brand awareness. It is important to involve purchasing, general service and finance and accounting in the process of selling and determining barter value. The compensation value provided by the company to the client must be the same value as the goods to be received by the company. Also, booking a spot for advertisement must only be done by the implementer section in the finance and accounting department once the MO is received and the internal package is approved. These steps will allow for the reconciliation between the $\mathrm{MO}$, internal package, advertisement that is displayed on company's website, and the barter goods received.

\section{Implementation and Analysis of Barter Goods Management}

\section{1) Acceptance of barter results.}

Barter items received from clients may be directed to the sales and general services departments depending on the type of goods received, if the goods require a large storage space, they are usually handed over to the general services department, and some of them are delivered to the finance and accounting department for storage (entrusted). In this case, the company does not have the specifications of the type of goods that can be stored in each department. If the goods are in the form of vouchers or tickets, the sales department may store and record the received barter items. Each of the sales persons responsible for the sales activities record the barter items in their respective internal documents. Information on the receipt is not forwarded to general services department or to the finance and accounting department. The relevant sales department is responsible for the inspection of the quality and quantity of goods received. If the barter goods are accepted by the general services section, the general services section matches the received item and the delivery order with the barter demand form obtained from the sales department on arrival of the goods. This matching is done because the initial approval of the barter sales by the sales department is not known to the general services department, as the amount or type of barter items that will be received from the client is not known and they have no way to check the barter receipt. The general services department records the types of goods obtained into their internal documents. The finance and accounting department records the transaction in the accounting journal to reflect the sales in the financial statements based on the MO information and the evidence presented with the 
issuance of the invoice. The finance and accounting department can only monitor the acceptance of barter items from clients based on the MO received from the sales department. This monitoring has not been consistently done because there is no clear provision identifying who the responsible party should be for barter goods management. Figure 2 shows the flow of barter proceeding process by the company.

\section{2) Expenditure of barter results:}

The application to barter goods may be made by all departments within the company with the approval of the head department of the requestor. It is addressed to the person holding the barter item, in other words, the sales or general services department. Based on observations and interviews conducted by the author, the expenditure of barter goods can be done without the approval of the department head of the requestor to accelerate the process of barter good expenditure to smoothen operations and for urgent event activities. The recording of the expenditure or use of barter must be made by each person responsible for the item, in their respective internal documents. The finance and accounting department is not involved in the approval of the request for the use of barter goods. Sales of barter goods may occur to meet cash needs if the goods are not used for operational activities. The party responsible for the item must seek approval from the respective department head, the departmental head of finance and accounting, and the CFO by making Inter Office Memorandum (IOM) barter sales. The money from the sale of barter goods is directed to the finance and accounting department. The determination of the selling price of this barter item must be determined by each person responsible for the goods at the prevailing market price. Figure 3 shows a summary of the process of expenditure or the use of barter proceeds.

\section{3) Monitoring of barter results:}

Each party holding the goods is responsible for the supervision of the barter goods that consists of the quality and quantity until their expiration date. The company has no mechanism to monitor the acceptance, use, and centralization of the barter lists. Based on observations and documentation by the author of the warehouse owned by the company and run by the general services and the finance and accounting departments, there are barter goods that cannot be sold as the quality of the goods is impaired due to damage or because they are approaching or even past the expiration date.

Based on the information obtained by the authors, one of the risks that can arise in the process of barter management is the loss of barter goods due to an unauthorized receiver (Risk V). This loss falls into the high-risk category. Acceptance of barter items from clients may be accepted by the sales and general services departments, especially for items that require large storage. Barter items received by the sales department are stored in their own desk drawers because there are no specific warehouses which increases the risk of losing the barter. Accordingly, it is possible that the barter goods are not properly monitored so that there can be a loss. For this risk, the company's method of control is for finance to monitor the receipt of barter goods. The finance and accounting department has not consistently monitored the acceptance of barter goods based on the MO because there is no clear provision on barter goods management.

Another risk that can arise is the expenditure or use of unauthorized barter goods (Risk VI). This risk falls into the high-risk category, due to the recording of the receipt of barter goods conducted by each party receiving the goods. The recording of the use of goods is also done by each party, especially for barter goods stored in an unsafe place. All of these actions can result in a loss of control over the use of barter goods because there is no separation of duties between the receipt, dispensing, recording, and the custodian. Further, the goods are stored in a place that is easily accessible to others. To overcome this loss of control, any expenditure or use of barter goods must be approved by the requestor's boss. However, there is no written provision stating that the expenditure on the use of barter goods must be approved by the requestor's boss, which does not always happen due to operational reasons. Consequently, the use of the goods becomes invalid and results in fraud. Also, the storage of goods is not centralized and they can be stored privately. The loss of barter goods due to theft (Risks VII) is also in a highrisk category due to the process of barter management. Based on the author's observations author, the barter items received by sales personnel that are stored in cabinets or desk drawers can be accessed by other parties. The sales room is easily accessible because the workplace of the sales and marketing division is open-plan so there is no specific room that separates this division from other divisions. Besides, because of active sales movement, it is often empty.

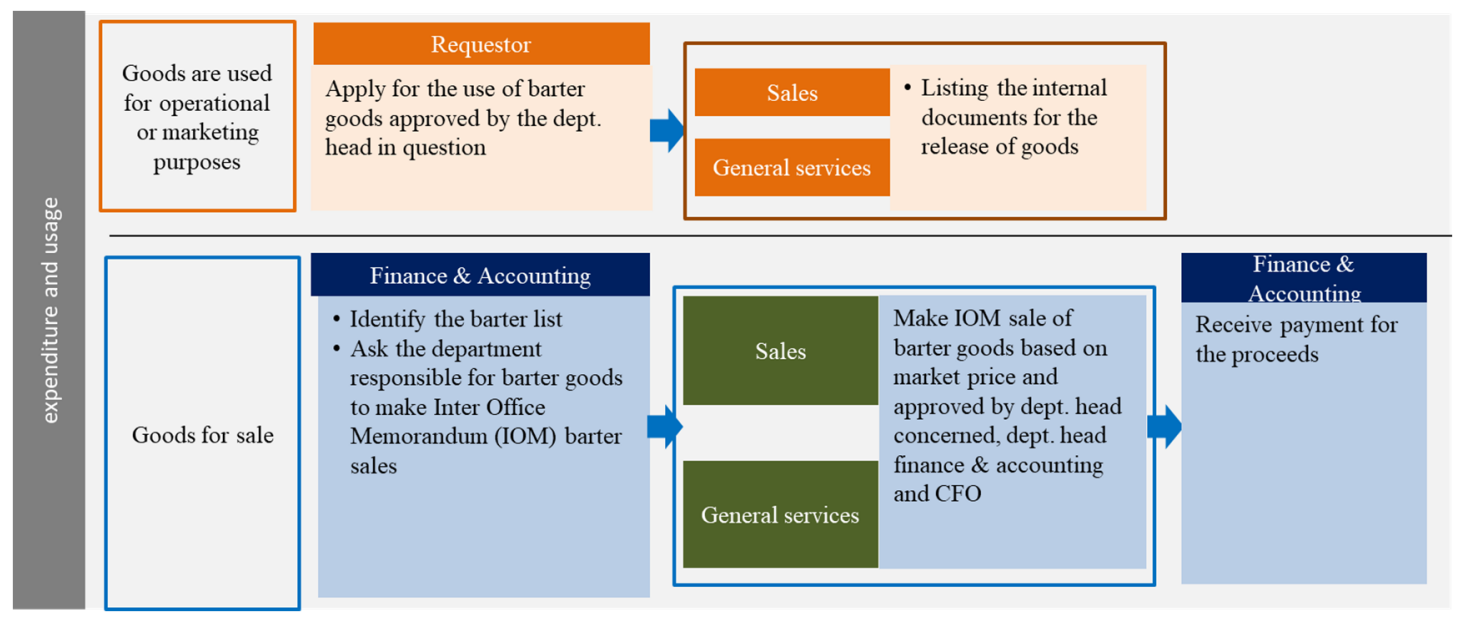

Fig. 2. Process of Expenditure or Use of Barter Goods 
Observation of the general services warehouse shows that the goods storage warehouse is combined with the warehouse for the human resources (HR) department, so the goods can get mixed because there is no identification of goods. Also, there are barter goods located outside the warehouse storage room that can be easily accessed by outsiders. The general services department room and warehouse are not always closed for easy outside access. According to the documentation received by the author, the barter list managed by the finance and accounting department only names the goods, the amount, and value of the item without mentioning the expiry date or date of manufacture, date of acquisition, and other details. In the absence of a marked record it will be difficult to determine the follow-up required for the goods. The list of barter goods managed by general services does not provide information about the movement of goods regarding the date of receipt and usage, so the purpose of usage is unknown. Observations made by the author on the warehouses of the departments of general services and finance and accounting, indicate that the accumulation of barter goods in the warehouse cannot be sold due to a variety of reasons such as approaching expiration date. A way to overcome this risk is for the company to ensure that the barter proceeds be stored in a safe place; this would require a barter list of type, value, and amount of goods. In practice, barter items received are stored in places that are not entirely secure such as cabinets or drawers. Also, the access to the storage warehouse is not properly controlled so that outside parties could access it which could be detrimental to the company. This lack of security could not only result in the loss of barter goods but it could also affect the security of the office which is openplan, and other items and documents may be lost. By having a barter list, the company could be able to monitor the goods, but the company's list does not include the necessary detailed information on monitoring and follow-up, moreover the list of barter items is decentralized to various parties, and the implementation of barter monitoring is inconsistent. Therefore, although there is internal control, it is inadequate which results in this risk staying in high-risk level. The lack of clear provisions on the management of this barter result further undermine the internal control.

Based on the analysis of risk and internal control, the authors argue that the company has weak control in the management process of the results of barter; it does not even have written regulations.

\section{Improvement in the management of barter results}

In relation to internal control risks and weaknesses in the company's management of barter results owned, the company must stablish important practices such as the acceptance of all barter items received from clients must be done by the general services department. The general services department is responsible for checking the quality and suitability of the items received, comparing it to the barter demand form, and keeping it in a safe place. Also, the department must make and submit a list of goods arrivals along with the change in goods usage to the finance and accounting department for financial control and reconciliation between the internal package, MO, advertisement serving, receipt of goods, and for inventory purposes. The general services department must store the barter items in a safe place, in locked storage warehouses that can only be accessed by general services department personnel. If, due to space constraints, storage warehouses must be combined with others, then the barter items must be marked to show that they belong to general services and there should be limited access by other parties.

When goods have not been received by the company, the finance control section must follow up with the sales, marketing, and general services departments for reconciliation purposes. The general services department should report to the sales or marketing department if there is damage to the bartered goods or if the goods are approaching their expiration dates or obsolescence to determine whether they can be used for operational purposes or be sold. In the event of a sale of bartered goods, the receipt of the money for their sale must be submitted to the finance and accounting department for recording purposes. Payments must be transferred to the finance and accounting department, and if that is not possible then the general services department must hand over the proceeds of sale on the same day as the occurrence of the sale by submitting a receipt of goods and money. Also, the demand for barter goods may only be made if the approval of a barter request is complete and the goods are available at the warehouse.

\section{E. Implementation and Analysis of Incentive Mechanisms}

The main purpose of providing incentives is to encourage employees to increase productivity to benefit the company. For the incentive scheme to be successful, it should be well planned. Incentive systems that are not properly designed can lead to company loss due to invalid sales value. The incentives given to sales staff are calculated based on the total sales achieved that consists of ordinary sales (nonbarter) and barter sales. The achievement of barter sales itself, is calculated as follows:

a. If barter goods are used for operational activities, then the achievement is calculated at $100 \%$ of barter sales value.

b. If barter goods are used for marketing purposes, then the achievement is calculated at $50 \%$ of barter sales value.

c. If barter goods are sold, then the achievement is calculated at $100 \%$ of the value from the sale of the barter goods. 


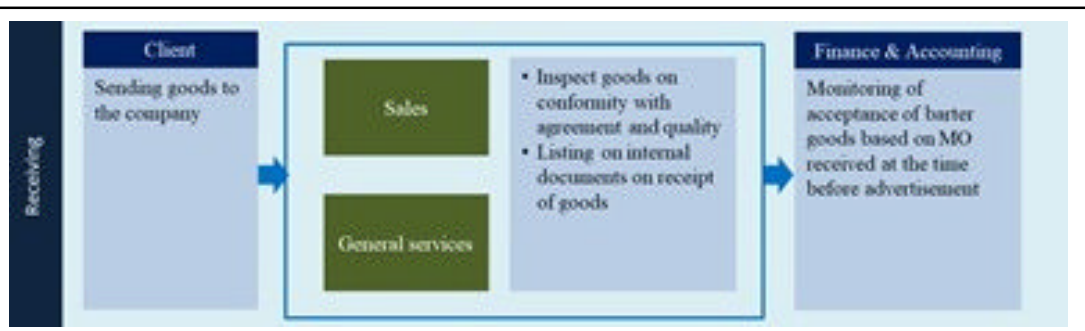

Fig. 3. Acceptance of Barter Goods

Incentives are a risk in the financial statements in respect of valuation and existence because incentives are awarded on the basis of invalid sales values (Risk VIII). This risk is considered as high-risk because incentives are calculated based on the achievement of barter sales that might be incorrect. Also, as the company does not have adequate records of barter management, it is possible that the incentive calculation schemes for barter sales components are misused. The sales department may realize that all the barter items are used for operational activities and that achievements can be calculated in full. The control that the company has in the achievement of barter sales is calculated only when the goods are used or sold. Internal control, at the time of barter value determination, is insufficient and it can affect incentive calculations. Internal control cannot overcome the fraud that occurred because of the incorrect reporting on the use of barter goods as the basis for calculating the value of barter sales achieved. Accordingly, researcher concluded that the company needs to improve its incentive mechanisms.

\section{F. Improvement in incentive mechanism}

The author suggests that it is necessary to improve the determination of the value of the incentives and the management of the barter proceeds because the incentive mechanisms of firms are largely determined by the value of them. Alternatively, the company can exclude the sale of barter from the calculation of sales targets or it can form a special section to conduct barter transactions and exclude the achievement of barter goods in the calculation of incentives. The company will need to understand its needs through effective planning to ensure that the bartered goods and transactions meet company needs. In so doing, the company will be able to choose between the two alternatives. Incentive calculations also need to be approved by the head of HR as the basis for making IOM incentive payment submissions to the finance and accounting department and the CFO.

It is expected that the objectives of the internal control can be achieved by implementing the policy suggested by the author, in each section of the company. The policy and business processes must be understood by all parties within the company to ensure that they function. Therefore, it is necessary to continuously train employees so that the policy and business processes are understandable, including the risks that can occur in every process and the internal control measures that the company has that can mitigate those risks. Companies can use face-to-face training by inviting stakeholders or use other methods that suit the company's circumstances.

\section{CONCLUSION AND \\ RECOMMENDATION}

\section{A. Conclusion}

Based on the analysis of the internal control design in the barter process that covers the sales process and determining barter value, the barter goods management and barter sales achievement, the researchers reached the following conclusions:

\section{a. Sales process and barter value determination}

There is insufficient segregation of duties between the determination of the sales and barter value determination which reflects the lack of coordination between the sales, marketing, purchasing and general services departments in establishing the needs and fair value of the barter. In addition, the marketing department books slots for advertisements on the company's website without any independent reconciliation of the value determination, goods receipt, use of goods, and the booking of the advertisement slots. Above all, the risks cannot be mitigated properly.

\section{b. Barter goods management}

In barter goods management, there is no clear guidance on who can accept and manage the barter items received from clients, resulting in the uncontrolled acceptance, use and monitoring of barter goods. Also, inadequate barter storage can lead to loss of barter goods.

\section{c. Methods of calculating barter performance}

Incorrect sales achievement methods are also a weakness of internal control in the barter system within the company, because incentives for the barter are calculated based on the total sales achieved. They consist of ordinary sales (nonbarter) and barter sales which include the use of barter goods. Also, the achievement of targets is strongly influenced by the barter value determination, which currently falls under the marketing department.

\section{B. Recommendation}

Internal controls are necessary to overcome the barter process weaknesses, so that barter activity can continue. In this study, the researchers provide suggestions in the form of policies and procedures related to sales and barter value determination, barter goods management, and the calculation of barter achievement by considering the effectiveness and internal control as following:

a. Sales process and barter value determination 
- The general services department must approve the needs and availability of goods and to provide input on the selling power of the goods.

There should be coordination between the purchasing and planning and implementation sections in determining the fairness of barter value compared to advertising given to client.

- The finance and accounting department must approve the internal package in respect of the re-examination of the barter transaction and the need for the reconciliation of the internal package, $\mathrm{MO}$, receipt of goods, and the running of advertisement.

- The implementer section from the marketing department must be transferred to the finance and accounting department. The implementer must be responsible for the barter sales reconciliation between the internal package, MO, receipt of goods, and the running of the advertisement. This transfer will also help the resource efficiency of the company.

b. Barter goods management

- Acceptance of barter goods should be directed to the general services department for recording. General services should monitor the movement of barter goods and store them in a safe place.

- All barter transactions must be reported to the finance and accounting department, consisting of sales, goods receipt, and the running of the advertisements together with the issuance of invoices and records in the financial statements

\section{c. Method of calculating barter performance}

Companies can choose recommendations that are considered appropriate to overcome the existing risks.

- Change the process for the incentive method and barter goods management in accordance with the researchers' proposal in the previous section so that the sales value can be correctly determined and the use of barter goods can be correctly recorded.

- Exclude barter sales from the sales targets calculation, so the sales department does not make barter sales solely to meet sales targets. The fulfillment of barter goods can be done by other parties that are specially formed to conduct barter transactions. Barter achievements should not be included in incentive calculations.

The above recommendations are expected to add value to the company by confronting the barter risks and weaknesses in internal control. In this research, the limitations experienced by the researchers consist of limited time and limited access to corporate finance data. As a result, the researchers could only conduct analysis based on the information received such as the design of company's internal control. Future researchers can study the implementation of internal control on the barter process from other points of view in more detail, including accounting and taxation aspects that would add to the research on barter sales.

\section{REFERENCES}

[1] Nielsen (2017). The New Trend Among Indonesia's Netizens-How and where digital consumers are watching content online. $<$ https://kupdf.com/download/nielsen-indonesia-digital-consumer26072017pdf_5a8abfdde2b6f5cd431d6571_pdf $>$

[2] Healey, N. M. (1996). Why is Corporate Barter? Business Economics, 31(2), 36

[3] Arens, A. A., Elder, R. J., \& Beasley, M. S. (2014). Auditing and assurance services: An integrated approach (15th ed.). New Jersey: Pearson Prentice Hall.

[4] Romney, M. B., \& Steinbart, P. J. (2015). Accounting information system (13th ed.). Pearson Education Limited.

[5] Kassaye, W. W., \& Vaccaro, J. P. (1993). TV stations use of barter to finance programs and advertisements. Journal of Advertising Research, 33, 40.

[6] Hasibuan, H., \& Malayu, S.P (2016). Manajemen Sumber Daya Manusia (ed.19). Jakarta: Bumi Aksara.

[7] Tambunan, R. M. (2013). Standard Operating Procedures (SOP) (2nd ed.). Jakarta: Maiestas Publishing.

[8] Yin, R. K. (2015). Studi Kasus: Desain dan Metode (14th ed.) Translator: M.D. Mudzakir. Jakarta: Rajagrafindo Persada. 